\title{
Workers in an ethnographic archive: On the strategies of (re-)constructing the past
}

\author{
Grażyna Ewa Karpińska
}

Prof. Grażyna Ewa Karpińska, PhD.

University of Lodz, Faculty of Philosophy and History

Institute of Ethnology and Cultural Anthropology

Poland

e-mail: grazyna.karpinska@uni.lodz.pl

ORCID 0000-0003-2102-774X

Muzeológia a kultúrne dedičstvo, 2022, 10:1:105-117

DOI: $10.46284 / \mathrm{mkd} .2022 .10 .1 .6$

Workers in an ethnographic archive: On the strategies of (re-)constructing the past

The article describes a collection of 9,000 photographs with captions - entries to a worker-oriented photographic contest - and the paths by which they came from private albums through the contest and museum exhibitions, until they found a place in the ethnographic archive of the Lódź University and in a digital repository. Having left household archives, they became a part of a public heritage rooted in, and dependent on, various historical contexts. Each procedure in some way determined the fortunes of the collection and constituted a choice that imparted a certain shape and meaning to the photographs.

Keywords: ethnographic archive, workers, photographs, digital repository Workers in the 19th and 20th century, heritage

\section{Introduction}

The task of an ethnographic archive ${ }^{1}$ is to preserve documents pertaining to various phenomena visible in culture and society, resulting from research conducted individually or collectively, arising from fieldwork, archival research, library research and other activities of ethnologists/anthropologists. ${ }^{2}$ They may include interviews, that is, recorded and/or transcribed conversations with individual people on a certain subject, as well as observations

\footnotetext{
${ }^{1}$ In Poland, ethnographic archives are not institutionally subordinate to state archives. State archives conduct their activity with respect to the state archival resources as defined by the Act on National Archive Resources and Archives; they are a part of the national archive network and are subordinate to the Head Office of the State Archives. State archives are created and dissolved by the Ministry of Culture and National Heritage of the Republic of Poland Journal of Laws, year 2020, no. 164]. Ethnographic archives, in contrast, are organisational units of varying degree and method of institutionalisation, depending on the culture of the given institution and the solutions accepted therein; they can be separate units in the organisational structure or, conversely, units that are not discrete but only subordinate to the person who keeps them. The activity of ethnographic archives in Poland is characterised by considerable freedom resulting from the absence of formal directives. Cf. WRÓBLEWSKI, F. Archiwa a etnografia. In: Kultura i Społeczeństwo, 2019 (1), pp. 45-67.

2 The names ethnography/ethnology/anthropology suggest a certain terminological polysemy, but they refer to the history of a single discipline, one concerned with human beings and their culture, and they reflect the variety of scholarly approaches and practices within its scope. Today, ethnography is understood, following the Englishlanguage literature, as a method in field research concerning socio-cultural realities. Ethnographic field research is not only an achievement of the discipline, but also a distinguishing element that defines its identity. Field research plays a crucial role in the research practice of an ethnologist/anthropologist.
} 
conducted in the field, field notes, drawings, site plans, photographs, including ones donated by private individuals (in the form of scans or reproductions), documents from archives and press articles. Materials, such as photographs or memoirs, are also placed in ethnographic archives by various institutions, associations or private individuals. Once there, the congregation of such materials is set in a proper order and used as a basis for further analyses and interpretations.

An ethnographic archive is a scientific archive. In the traditional perception, it is a physical place, a repository with certain definite collections and a set of regulations that delineate access to them. By becoming a fundamental tool in archiving documents, digitisation has made it necessary to alter this traditional model of thinking about archives, including ethnographic ones, their functioning and their way of being perceived by the scholarly community. The twenty-first century has brought a rapid development in digital archives, that is archives with no location, whose resources do not exist in physical space. Searching their resources occurs without the help of an archivist; the users construct their perceptions of the past by themselves, by searching for or entering appropriate words. Collections are created in digital space, archived and recorded in digital space, and accessed by means of a computer, ${ }^{3}$ and thus direct contact with the archival material has been lost. In fact, Marcin Wilkowski writes about a "sign of an ending of a certain ethos in archive work, based on the experience of a direct contact with historical documents, which are now accessed online". ${ }^{4}$

In the current article I present a collection of nine thousand photographs entered into a worker photography contest, subsequently conveyed to the Bronisława Kopczyńska-Jaworska Ethnographic Archive at the Institute of Ethnology and Cultural Anthropology of the University of Lodz (Poland) and deposited in the digital repository Workers in the 19th and 20 th century. ${ }^{5}$ I describe their fortunes before they arrived in the digital repository. I relate the changes in their status and the various actions which have resulted in their becoming a part of the public cultural heritage, that is, a legacy rooted in the past and referring to the history of the worker milieus.

\section{In a household archive}

Photographs hold a very important place among family mementoes and, at the same time, constitute their most frequent form. In the worker milieus, the commemorative role of photographs prevailed over all their other functions; the workers used them to decorate interiors, displaying chiefly marriage photographs or photographs of children. ${ }^{6}$

Carefully placed in family albums, kept in boxes and drawers or stashed in lofts and cellars, photographs constitute a framework for remembrance. They are carriers of the family memory, which consists of persons, events, successes, turning points in family life and professional life, objects and qualities reconstructed in the course of family reminiscences. The memory is refreshed through photographs; they make it easier to recall events. In household archives photographs are meticulously preserved, collected in memoriam - to attest to the continuity

\footnotetext{
${ }^{3}$ MANOVICH, Lev. The Language of New Media. Massachusetts: MIT Press, 2001, p. 105.

${ }^{4}$ WILKOWSKI, Marcin. Wprowadzenie do historii cyfrowej. Gdańsk: Instytut kultury miejskiej, 2013, p. 51, http://dane. historiaimedia.org/hc/2/wprowadzenie_do_historii_cyfrowej_wilkowski.pdf (accessed 24 February 2021)

${ }^{5}$ The Workers in the 19th and 20th century digital repository can be accessed at https:// fotografierobotnikow.uni.lodz. $\mathrm{pl} /$

${ }^{6}$ This is shown by, among others, the research on the social dimensions of photographs as conducted by Pierre Bourdieu's team. See BOURDIEU, Pierre, BOLTANSKI, Luc, CASTEL, Robert, CHAMBOREDON, Jean-Claude, SCHNAPPER, Dominique. Photography: A Middle-brow Art. Cambridge: Polity Press, 1998.
} 
of generations, to bring to mind the dead or distant loves ones, and to arouse emotions and memories. They are viewed spontaneously, "in passing". Sławomir Sikora suggests that the universe of private photographs should be treated "like the universe of personal names, especially if we go a little back in time to when photography was not yet so widespread, not to say commonplace. This would be the universe in which a photograph retained its magical power, the potent connection with its referent, the powerful ontological mark." ${ }^{\prime 7}$ Commenting on a collection of photographs of Polish peasants (also resulting from a contest), ${ }^{8}$ Roch Sulima stressed that a photograph, which used to be interpreted as a "shadow" of a person featured therein, turned into a substitute for that person, "stood for the sitters themselves", and thus was equal to a human being. ${ }^{9}$ In his view, it was the photograph that overturned the monopoly of the spoken word when it began to replace verbal contents and took over its role in the process of constructing the memories held by members of a family or a community. ${ }^{10}$ Photographs sent overseas or to the wartime trenches, kept in a box or a drawer, displayed on shelves or dressers, or affixed to the pages of albums recreated family connections and stood in place of the actual persons. In this way a photograph marks its presence as a memento which holds a permanent place in private space. This status is conferred on a photograph by the work of memory, that is by memories, longing and nostalgia, ${ }^{11}$ which materialise in it "to stop time, to block the work of forgetting", ${ }^{12}$ and thus belong to a person more solidly than words. Also, photographs constitute a confirmation of words, imbuing them with truth and obviousness.

\section{The contest}

In the year 1985 the editorial boards of the Pryekrój and Polityka weeklies and the Fotografia quarterly announced a contest for worker-related photographs held in household archives. The organisers called for photos "illustrating the formation of the working class in the Polish territories until 1945, the year when industry in Poland was nationalised, and the first years of the country's reconstruction". ${ }^{13}$ In response, 909 readers from Poland and abroad sent in 10,500 photographs with detailed descriptions of the persons and events they featured.

Photographs sent in for the contest show workers and their families, described by name and surname in the captions - men and women who did physical labour in industrial plants or had the legal status of workers employed at a variety of enterprises, including agriculture and forestry. They are those who built cities and factories, the Gdynia port and the Silesia-toGdynia coal transport railway; who laid water pipes and electricity lines; and who constructed roads. There are photographs of activists from professional associations and worker organisations; members of work teams from foundries, mines and factories; workers standing

\footnotetext{
${ }^{7}$ SIKORA, Sławomir. Między przezroczystością a nieprzezroczystością: aporia fotografii. In: PELCZYŃSKI, Grzegorz, VORBRICH, Ryszard (eds), Antropologia wobec fotografii i filmu. Poznań: Biblioteka Telgte, 2004 , p. 11.

${ }^{8}$ This was the contest "Fotografia polskiej wsi do 1948 roku" (Polish villages before 1948 in photographs) organised in 1983 by the editorial boards of the Nowa Wies weekly and Fotografia quarterly.

9 SULIMA, Roch. Stowo $i$ etos. Szkice o kulturze. Kraków: Fundacja Artystyczna Związku Młodzieży Wiejskiej „Galicja”,1992, pp. 120, 122.

${ }^{10}$ SULIMA, Stowo..., pp. 118-119.

${ }^{11}$ FRYDRYCZAK, Beata. Świat jako kolekecja. Próba analizy estetycznej natury nowoczesności. Poznań: Wydawnictwo Fundacji Humaniora, 2002, p. 175.

${ }^{12}$ NORA, Pierre. Between Memory and History: les lieux de mémoire. In: Representations, 1989, no 26 (Spring), p. 19.

${ }^{13}$ GARLICKA, Aleksandra. Druga wystawa fotografii robotniczej. In: KURASIAK, Małgorzata (ed.), Robotnicy. II wystawa fotografii robotniczej. Zdjeccia z lat 1881-1946. Katalog wystawy. Warszawa: Wydawnictwo Centralnego Biura Wystaw Artystycznych, 1989, p. 7.
} 
at machines, celebrating holidays in family circles, walking in the streets, relaxing in parks or in the countryside, or dressed in the uniforms of various armies during the Great War. There are their school photographs, first communion photographs, and wedding, christening and funeral photographs. The contestants sent in photographs of forced labourers in German factories during the Second World War, economic émigrés in the French mines or American production plants in the late nineteenth and early twentieth centuries or in the inter-war period, and records of the great migration of villagers to the city. The collection includes photographs of coalminer families, railway-worker families, stonemason families and weaver families, some of them collected over decades, in some cases since the last years of the nineteenth century. The earliest one dates from the year 1881 and shows a Siemianowice foundry worker with his family; the latest were taken in the 1980s, even though the organisers had set 3 January 1946 (the day the decree on the nationalisation of Polish industry was issued) as the closing date.

Most of the photographs were described in keeping with the guidelines set by the jury: 1) the date the photograph was taken (year, month, day); 2) who or what was featured in it; 3) what event it documented; 4) where it was taken; 5) where the sitters resided; 6) where they came from; 7) where they were employed (in which factory, workshop, in what capacity); 8) later fortunes of the sitters; 9) in instances where the photograph showed a residential or factory building, a detailed description of where it stood, who owned it and who worked in it; and 10) who took the photograph.

In some cases, the descriptions were veritable family sagas; in others, the histories of the factories or workshops, and the people employed therein, were related. Many photographs bore dedications or captions on their reverse side. Apart from those, and the stories and explanations written on separate sheets of paper appended to the photographs, there are also comments or data regarding a given sitter, a given place, event, situation or gesture. There are also descriptions relating, albeit fragmentarily, the experiences or histories of the persons who sent in the photographs, even if not shown in them. As noted by Magdalena Sztandara, such descriptions, dedications and captions "put the photographs in context, 'ascribed' them, so to speak, to a definite fragment of reality; their attachment to reality makes the photographs concrete. Words impart an additional meaning, but at the same time they invalidate the photograph's powerful polysemy, leaving it as an almost unequivocal statement."14

The jury gave 62 prizes and 150 lesser awards. The prizes and awards were funded by ministers, voivodes, mayors, social organisations, scholarly associations, industrial units, museums and publishing houses.

The contest organisers concluded that the photographs and their captions gave not only a picture of the worker community throughout a part of its history, but also a picture of Poland's industrial development. They emphasised that those photographs and their captions made it possible to discern, for the first time ever, the signs of the great social transformations which the Polish worker community underwent in the period 1881-1945. It was therefore decided to make these photographs, and the "historical values" they carried, available to the wider public.

\footnotetext{
${ }^{14}$ SZTANDARA, Małgorzata. Fotografia - „opowieść” o skończoności życia. In: GLEŃ, Adrian, KOWALSKI, Piotr (eds.), Obecność i przemijanie. Fenomen poczatku i końca w kulturze i literaturze wspótczesnej. Opole: Wydawnictwo Uniwersytetu Opolskiego, 2001, p. 147.
} 


\section{The exhibition}

The exhibition "Robotnicy" (The Workers) consisted of photographs that had won prizes and awards in the contest and of photographs on the subject of labour dating from the mid-nineteenth century and the inter-war period that came from museum repositories. The exhibition was on show in May 1989 in the "Zachęta" National Art Gallery in Warsaw and subsequently in the museums in Lodz, Sosnowiec, Częstochowa and Cracow.

The script for the exhibition was arranged so as to construct "our shared national history"15 from private photographs; the resulting image was compliant with the chronology of historical events. The first section focused on the history of the working class in the Polish territories under the Partitions. The second one showed the great migrations of workers during the First World War; this section included portraits of workers conscripted into various armies and the photographs illustrating how worker teams were relocated together with factory machinery and equipment. The following section was devoted to the Second Commonwealth. Industrial plants of various sizes and new construction projects, such as the Gdynia seaport or the hydroelectric plant in Rożnów, were described through the actions of their workforce and the images of machines at which they worked and the edifices they built. The next section focused on the Polish workers' emigration to the mines in France or in America and on forced labour in German factories during the Second World War. The last section was dedicated to the workers' return from their forced or voluntary emigration. ${ }^{16}$

Historians - experts on economic history and the history of the worker movement - who were asked to provide a commentary to the exhibition perceived the photographs sent in for the contest as historical sources which authenticated the events or situations shown therein, documenting "how it had really been": the workers' everyday life, work or socio-political activity, and confirming historical theses. ${ }^{17}$ In other words, historians perceived worker photography, as Pierre Bourdieu would put it, as "a perfectly realistic and objective recording of the visible world", ${ }^{18}$ a source documenting what happened in the past, a quotation from reality which provided an empirical corroboration for historical theses.

\section{In an ethnographic archive}

In 1989, the contest organisers deposited the photographs in the ethnographic archive held at the Institute of Ethnology (today: Institute of Ethnology and Cultural Anthropology) of the University of Lodz. Once there, the post-contest materials were processed by ethnographers/ ethnologists. The photographs were photographed and the originals were sent back to their owners.

\footnotetext{
${ }^{15}$ GARLICKA, Druga wystawa..., p.12.

${ }^{16}$ GARLICKA, Druga wystawa..., pp. 12-13.

${ }^{17}$ For more, see KURASIAK, Małgorzata (ed.). Robotnicy. II wystawa fotografii robotniczej. Zdjecia z lat 1881-1946. Katalog mystawy. Warszawa: Wydawnictwo Centralnego Biura Wystaw Artystycznych, Warszawa 1989, pp. 16-30. More on this topic in KARPIŃSKA, Grażyna Ewa. Stare źródła w nowych mediach. O repozytorium cyfrowym zbioru „Robotnicy w XIX i XX wieku”. In: CHORAŻŻYZEWSKI, Waldemar, PIASEK, Wojciech, ROSA, Agnieszka (eds.), Toruńskie Konfrontacje Archiwalne. Nowa archiwistyka - Archiwa $i$ archiwistyka w późnonowoczesnym kontekśsie kulturonym. Toruń: Wydawnictwo Naukowe UMK, 2014, pp. 226-227.

${ }^{18}$ BOURDIEU, BOLTANSKI, CASTEL, CHAMBOREDON, SCHNAPPER. Photography..., p. 73.
} 
The photographed photographs received the status of reproductions (and a reproduction, as it has been put by Walter Benjamin, "enables the original to meet the beholder halfway"19), which gave them a new lease of life. Having been photographed with an analogue camera, they still remained tangible objects, physically existing in time and space and having a definite shape and texture. ${ }^{20}$ What the archive gave them, however, was a new, scientific framework - not only a metaphorical, but also a material one. The products of their being photographed were two objects of a dissimilar status: negatives on celluloid film and prints on paper. The prints, all made in the same size, and photocopied captions were placed in envelopes, whereas the negatives were numbered and placed in specially prepared albums. Each envelope was marked with the name of the locality/region to which the material pertained and an inventory number ascribed to it in the ethnographic archive. Handwritten sheets with the most important data concerning the photograph - the date and place it was taken, the name of its author (if it could be ascertained), the name and address of its owner, and the number of the corresponding negative - were also put into the envelopes. The photographs were thus archived and received the status of an archival document precisely in the manner documentation was described by Michel de Certeau: as "the gesture of setting aside, of putting together, of transforming certain classified objects into 'documents.' [...] In reality [this gesture] consists in producing such documents by dint of copying, transcribing, or photographing these objects, simultaneously changing their locus and their status." 21

Passing into a scientific archive, the photograph-objects, which used to be family mementoes, became archived document-objects; a transformation of "something which had its own definite status and role into something else which functions differently" 22 has thus occurred. The archive became a home for them (they were placed "under house arrest", as Derrida would have it), and the care of them and their meanings - that is, the right to interpret them and set them in order - was taken over by those who represented control, ${ }^{23}$ namely, the ethnographers/ethnologists. The photographs-as-images were transformed as well: already during the exhibition at the "Zachęta" Gallery in Warsaw they ceased to be what they had been for "their people", their relatives or children. The relation of ownership changes: the photographs passed from the private sphere into the public one and acquired a public character, by which "the difference between a mode of pictorial address which is primarily 'informational' and one which is 'sentimental' is obscured" and "a relation of abstract visual equivalence between pictures" 24 is established. They no longer aroused emotions as they were looked at by strangers; they were

\footnotetext{
${ }^{19}$ BENJAMIN, Walter. The Work of Art in the Age of Mechanical Reproduction, translated by Harry Zohn. In: ARENDT, Hannah (ed.), Illuminations. New York: Schocken Books, 1969, https://web.mit.edu/allanmc/www/ benjamin.pdf\#page=1\&zoom=auto,-193,798 (accessed 19 March 2021).

${ }^{20}$ Cf. GILLIAN, Rose. Visual Methodologies: An Introduction to the Interpretation of Visual Materials. London, Thousand Oaks, New Delhi: Sage Publications, 2007, pp. 237-257.

${ }^{21}$ de CERTEAU, Michel. The Writing of History, translated by Tom Conley. New York: Columbia University Press, 1988, p. 72.

${ }^{22}$ de CERTEAU. The Writing of History, p. 74.

${ }^{23}$ Cf. DERRIDA, Jacques. Archive Fever: A Freudian Impression, translated by E. Prenowitz. In: Diacritics, 1995, vol. 25, no 2, pp. 9-10, http://beforebefore.net/149a/w11/media/Derrida-Archive_Fever_A_Freudian_Impression. pdf (accessed 21 December 2020).

${ }^{24}$ SEKULA, Allan. Reading an archive: Photography between labour and capital. In: WELLS, Liz (ed.), The Photography Reader. London and New York: Routledge, 2002, p. 445.
} 
just images to them, no more than documents confirming what they showed ${ }^{25}-$ it might be said, following Paul Ricoeur, that the moment they passed through the doors of the archive, they were "absorbed into a mass of documents that are not all testimonies". They were also subjected to criticism and confronted with other documents and testimonies. ${ }^{26}$ The act of archiving these photographs was accomplished with the aim of preserving them to be used again in the future, and for the memory of the coming generations - which does not mean the absence of photographs understood as objects.

The process of archiving freed the photographs-turned-documents from the direct influence of the present time. ${ }^{27}$ For several years they lay locked in the drawers of the ethnographic archive; until in the second decade of the twenty-first century they were brought out and deposited in a digital repository.

\section{In a digital repository}

Being placed in a digital repository constituted the next transformation in the status of the worker photographs and their captions, one by which the collection acquired a still different shape. $^{28}$

The contemporary reality offers many activities and practices leading to, as de Certeau might put it, "operations upon documents" which are connected with a new understanding of what constitutes an archival document: they are not papers but computer files. The material dimension of a document has changed as well. ${ }^{29}$ Digitisation, that is "a social process whose element is the re-mediation of artefacts of historical heritage and making them accessible online as digital objects such as computer files and scans", ${ }^{30}$ is now a fundamental archiving tool.

The digitisation of an analogue photograph occurs outside the photographic camera, namely in a scanner that passes the scanned material onward to the computer. In other words, an analogue photograph, defined by minuscule grains and rays of light, is transformed into an image made of pixels, elementary particles of the on-screen image. In contrast to traditional photography, the existential foundation of digital photography is not anchored in concrete, physical material and photochemical processes, but in the numeric reality which constitutes a $\operatorname{skin}^{31}$ that makes material objects difficult to reach - in order to understand it, a human being must apply an appropriate program for the reading of it. The environment for such a photograph is the computer screen. Thus the photo-graph, an object written with light, has

\footnotetext{
${ }^{25}$ See KRACAUER, Siegfried. The Mass Ornament: Weimar Essays, translated by Th. Y. LEVIN. Cambridge - London: Harvard University Press, 1995, pp. 47-49.

${ }^{26}$ RICOEUR, Paul. Memory, History, Forgetting, translated by Kathleen Blamey and David Pellauer. The University of Chicago Press, 2006, p. 147.

${ }^{27}$ ERNST, Wolfgang. Archive, Storage, Entropy: Tempor(e)alities of Photography. In: PIJARSKI, Krzysztof (ed.), Archiwum jako projekt. The Archive as Project. Warszawa: Fundacja Archeologia Fotografii, 2011, p. 56.

${ }_{28}$ The "Digital Repository of the Workers in the 19th and 20th Century Photographic Collection" project was implemented in the years 2012-2015 as a part of the Ministry of Science and Higher Education's programme the National Programme for the Development of Humanities, research module 1.1. (no. 0078/FNiTP/H11/80/2011), headed by Prof. Grażyna Ewa Karpińska. The collection was placed in the depository under the address https:// fotografierobotnikow.uni.lodz.pl/.

${ }^{29}$ Cf. van DIJCK, José. Mediated Memories in the Digital Age. Standford: University Press, 2007.

30 WILKOWSKI, Marcin. Zwrot cyfrowy w edukacji historycznej. https://docs.google.com/document/ pub?id=13re0ciTIqXctMwjpDy4vXxqpp5D9yf7C8965xZB6vdI (accessed 16 December 2020).

${ }^{31}$ The term was introduced by Derrick de Kerckove. Cf. de KERCKHOVE, Derrick. The Skin of Culture: Investigating the New Electronic Reality. London: Gardens Book, 1998.
} 
been transformed into photo-data. ${ }^{32}$

Piotr Zawojski emphasises that "in terms of an existential experience, of the individual perception", a digital photograph, differences in the manner of its recording and distribution notwithstanding, "is not radically different from a traditional photograph". It continues to confirm, just as the analogue photograph did, the existence of some (photographic) reality by creating its pictorial representation which is to a greater or lesser extent based on the principle of reference; also, again like the analogue photograph, it is an expression of the human perception and experience of this reality. This means that a digitised and digitally treated photograph may be a substitute for a traditional photograph, but, as emphasised by Zawojski, "not in terms of a substitute as something of lesser quality that replaces the original, but in terms of a mutual interchangeability of objects having similar qualities". ${ }^{33}$ In the case of the repository of worker photographs, we are thus still in the realm of photography, only in the digital world: the repository is a place of storage and the photographs remain "icons" (that is images, representations, similarities) of a specific culture (in this case, the worker culture). In addition, photographs held in a digital repository continue to document the passage of time and the techniques of photographing, as well as bygone events, situations and persons - their faces, hands and clothes, machines at which they worked, the houses they built and lived in, and the objects they used. Thus, the photographs constitute a narrative about a bygone world, and this means that they can be used in telling stories.

Yet the process of digitisation and their placing in the digital repository imparted a new status on those photographs: they were deemed especially important and meaningful. This is, after all, another method of "meeting the beholder halfway" - and, as it seems, it is truly a meeting, because, in contrast to photographs held in a traditional ethnographic archive, these photographs can leave the archive's drawers and, being accessible twenty-four/seven, reach a broader public. Also, digitisation ennobles, so to speak, the images which have been thus transformed - not forgetting, however, that the digital reality removes the photographs-asobjects and their captions away from their old context and imbues them with a new quality. ${ }^{34}$

Traditionally, constructing an archive relies on creating a register of documents and classifying them. In digital media, the organisation of the archive is regulated by means of algorithms, ${ }^{35}$ and the method of arranging the collection is determined primarily by software. In the digital repository of worker photographs, the resources and their descriptions are managed by dLibra, a modern system enabling the creation of professional libraries and digital repositories and making their resources accessible to persons and systems active on the web. Thanks to this system, the repository is not a simple storage space for the worker heritage, where pictures would be only deposited, but a storage space arranged in a way that facilitates navigation: files and scans have titles and each photograph was indexed according to a classification system prepared specially for the purpose.

\footnotetext{
${ }^{32}$ BAUDRILLARD, Jean. Photography, or the Writing of Light, translated by Debora DEBRIX, 2000, https:/ /journals. uvic.ca/index.php/ctheory/article/view/14605/5462 (accessed 25 February 2021).

${ }^{33}$ ZAWOJSKI, Piotr. Elektroniczne obrazoświaty. Międry sztuka a technologiq. Kielce: Wydawnictwo Szumacher, 2000, p. 71.

${ }^{34}$ KARPIŃSKA, Stare źródła...; see too WILKOWSKI, Marcin. Co się dzieje z archiwum w internecie? Killea watkón teoretycznych. In: ZIĘTAL, Katarzyna (ed.) Arcbiwistyka spoteczna. Warszawa: Ośrodek KARTA, 2013, pp. 53-58, accessed 28 February 2021, https://ksiegarnia.karta.org.pl/wp-content/uploads/2017/11/Archiwa_spoleczne_ podrecznik.pdf

${ }^{35}$ ERNST, Archive, Storage..., p. 76.
} 
The captions and descriptions provided by the owners of the photographs, as well as the captions written on their reverses, served as a basis for developing the repository's structure and constructing the metadata set. They were compared with the given image and as a result they indicated the possible search object. Metadata were entered into the repository according to the following scheme: date, place (location), photographer, photograph type, persons shown therein, comments. Key words with which the photographs were described were drawn from a thesaurus consisting of the following sections: City/Village; Work; Outside work; Home; Clothing in city milieus; Rituals, festivals, gatherings.

The description of every photograph entered into the repository consists of two layers. One, which is visible to the user, consists of attributes and key words which identify the photograph and make it possible to browse the set online and search for the objects of interest. The other is the description layer, which is not visible to the user. This is the so-called inner description; it contains much more information about the photograph that the data accessible through the online browser. This set is created for documentation and archiving purposes (for instance, it contains the address of the photograph's sender); it is protected by copyright and personal data protection regulations, and it is not made public. ${ }^{36}$

\section{(Re-)constructing the past in an archive}

The way of navigating the past in the Workers in the 19th and 20th century repository is defined by the modern perspective, as is the case with traditional archives. The modern point of view also determines the construction of the past reality: the presented reality is metaphorically appropriated with the future uses of the resources in mind. This means that when the collection of photographs of workers assumed the form of cultural heritage, it became a construct created in the process of designing the programme of the exhibition which followed the contest, or in the process of filing and captioning it in the ethnographic archive. A digital repository is a construct as well. Allan Sekula emphasises that no archive is neutral - it always embodies "the power inherent in accumulation, collection, and hoarding as well as that power inherent in the command of the lexicon and rules of a language". ${ }^{37}$ Furthermore, as Sekula notes, an efficiently functioning archive needs to employ bureaucratic measures similar to the ones used by banks, police file archives, museums or zoological gardens. "Thus, the archival perspective is closer to that of the capitalist, the professional positivist, the bureaucrat and the engineer - not to mention the connoisseur - than it is to that of the working class. Generally speaking, working-class culture is not built on such high ground." 38

The past, which is invariably inaccessible to us, forms constellations which attain their "now" in their recognisability during a specific moment in time. Each archive imposes a certain order on its contents. On the one hand, the classification applied to the Workers in the 19th and 20th century digital repository is designed to make it easier for the scholar to navigate the images and records from the past; on the other, it should be remembered that the images in the repository are perceived by Internet users as files, and thus their value is indicated and measured by "the

\footnotetext{
${ }^{36}$ In the year 1985 no-one thought about this aspect which is so important today. According to Polish law, the contents of publications found in the repository is protected by copyright and by general data protection regulations with respect to the persons shown in the photographs. Regulations concerning the use of the repository are found at http:/ /lodzregion.uni.lodz.pl/?page_id=110

${ }^{37}$ SEKULA, Reading an archive..., p. 446.

${ }^{38}$ SEKULA, Reading an archive..., p. 446.
} 
manner of dealing with them as files", which are usually arranged into folders. Furthermore, photographs viewed via the Internet have a certain duality to them. On the one hand, the user is looking at them as images in their own right, as captured scenes from the past reflecting the past reality; on the other, as Rafal Drozdowski puts it, "he or she is also looking at them as links (both in the literal and a metaphorical sense)" referring to other photographs in the repository, revealing the logic and structure of their interrelations. ${ }^{40}$

It should be remembered that the essence of archiving lies in imposing order by means of describing, naming and the choosing of appropriate key words. As Lutz Dammbeck stated in an interview, "an archive must be useful, that is, a person should be able to read it, and this is why its structure must be carefully considered [...]. Otherwise it will be just a heap of material." ${ }^{41}$ Thus, to conclude with Sekula's apt statement:

Photographer, archivist, editor and curator can all claim [...] to be merely passing on a neutral reflection of an already established state of affairs. Underlying this process of professional denial is a commonsensical empiricism. The photograph reflects reality. The archive accurately catalogues the ensemble of reflections, and so on.

Even if one admits - as is common enough nowadays - that the photograph interprets reality, it might still follow that the archive accurately catalogues the ensemble of interpretations, and so on again. Songs of the innocence of discovery can be sung at any point. Thus, the "naturalization of the cultural" $[\ldots]$ is repeated and reinforced at virtually every level of the cultural apparatus unless it is interrupted by criticism. ${ }^{42}$

\section{Conclusion}

Workers' photographs are a collection not only referring to, but also actualising the past, summoning it into the present. The photographs included in the ethnographic archive and the digital repository have ceased to function as a hermetically sealed collection isolated from any external influence. Having left private albums, they became a part of public heritage, embedded in various historical contexts and dependent thereon.

It is a process, not a form or type of material, that constitutes the fundamental feature of heritage. "Heritage is everything contemporary people opt to select from the past they have themselves created for current use or to pass down to posterity", notes Gregory J.

\footnotetext{
39 DROZDOWSKI, Rafał. Zdjęcia w sieci. Kierunkująca i na-znaczająca rama prezentacyjna Internetu. In: FERENC Tomasz, OLECHNICKI Krzysztof (eds.), Obrazy w sieci. Socjologia i antropologia ikonosfery Internetu. Toruń: Wydawnictwo Naukowe UAM, 2009, p. 20.

${ }^{40}$ DROZDOWSKI, Zdjęcia w sieci..., p. 21.

${ }^{41}$ DAMMBECK Lutz. Konstrukcja i estetyzacja archiwów/The Construction \& Aestheticisation of Archives. In: ZIÓŁKOWSKA, Magdalena, LEŚNIAK, Andrzej (eds.), Tytuł roboczy: archiwum \# 1. Lódź: ms2 Muzeum Sztuki, 2008, p. 52.

42 SEKULA, Reading an archive..., pp. 446-447.

${ }^{43}$ JENSEN, Ulfe J. Cultural Heritage, Liberal Education, and Human Flourishing. In: AVRAMI, Erica, MASON, Randall, de la TORRE, Marta. (eds.), Values and Heritage Conservation: Research Report. Los Angeles: The Getty Conservation Institute, 2000, pp. 38-43.
} 
Ashworth. ${ }^{44}$ The definition of this concept is now shifting towards the very subjective choice of us as the community that has become the current owner, not - as previously thought - the depositary, of the past. As Murzyn observes: "Heritage is a dynamic concept, a term that cannot be defined and determined once and for all. It is continuously chosen and shaped anew." ${ }^{45}$ In this framework, it is justified to state that the selection of workers' photographs included in the digital repository does not have a "predetermined final state", 46 but ought to be perceived in terms of incomplete knowledge, a collection which can never be full. After being indexed and catalogued, the collection undergoes no process until the moment when it begins to be browsed, used and incorporated into narration. ${ }^{47}$ Neither should it be considered a manifestation of "timeless, universal or constant values", meaning that "what we choose today may be disregarded tomorrow, and vice versa", 48 especially since, as Gregory J. Ashworth emphasises in a statement that may also be applied to the digital repository under analysis, the actions of heritage-makers "are usually directed towards creating a specific product. They focus their attention on the choice of the item itself, maintaining and managing it, not on how it is consumed. They consider the work done the moment the product is made available to its end users." ${ }^{49}$ Moreover, archives rarely close the debate on the past and heritage; they do not provide any "official interpretation of memory" and even generate new discussions on the shape thereof. This fact is pointed out by Mike Featherstone, who writes that an archive is a "site of accumulation of primary resources from which history is constructed", adding that constructing history depends on social, political and cultural interests, which fact often breeds overt and covert conflicts. ${ }^{50}$ This is a reason for worry and a cause of the ever-growing gap between the creators and the consumers of heritage, for whom this heritage may have entirely different meanings and undergo different practices.

\section{References}

ASHWORTH, Gregory J. (2007). Sfragmentaryzowane dziedzictwo: sfragmentaryzowany instrument sfragmentaryzowanej polityki. In: MURZYN, Monika A., PURCHLA, Jacek (eds). Driedzictwo kulturowe XXI wieku. Szanse i wyz̨wania. Kraków: Międzynarodowe Centrum Kultury, ISBN 978-83-89273-47-5.

BENJAMIN, Walter (1969). The Work of Art in the Age of Mechanical Reproduction, translated by Harry Zohn. In: ARENDT, Hannah (ed.), Illuminations. New York: Schocken Books, accessed 19 March 2021, https://web.mit.edu/allanmc/www/benjamin.pdf.

\footnotetext{
${ }^{44}$ ASHWORTH, Gregory J. Sfragmentaryzowane dziedzictwo: sfragmentaryzowany instrument sfragmentaryzowanej polityki. In: MURZYN, Monika A., PURCHLA, Jacek (eds.), Driedzictwo kulturowe XXI wieku. Szanse i wyzwania. Kraków: Międzynarodowe Centrum Kultury, 2007, p. 32.

${ }^{45}$ MURZYN, Monika A. Dziedzictwo kulturowe w okresie przemian: szanse i wyzwania. In: MURZYN, Monika A., PURCHLA, Jacek (eds.). Dz̧iedzictwo kulturowe XXI wieku. Sz̧anse i wyz̧wania. Kraków: Międzynarodowe Centrum Kultury, 2007, p. 153.

${ }^{46}$ ASHWORTH, Sfragmentaryzowane..., p. 32.

${ }^{47}$ This problem is discussed by Carolyn Steedman. See STEEDMAN, Carolyn. Dust: The Archive and Cultural History. Manchester: Manchester University Press, 2001, pp. 61-88.

${ }^{48}$ ASHWORTH, Sfragmentaryzowane..., p. 36.

${ }^{49}$ ASHWORTH, Sfragmentaryzowane...

${ }^{50}$ FEATHERSTONE, Mike. Archiving Cultures. In: The British Journal of Sociology, no 51 (1) pp. 168-169.
} 
G. E. Karpińska: Workers in an ethnographic archive: On the strategies of (re-)constructing the past

BAUDRILLARD, Jean (2000). Photography, or the Writing of Light, translated by Debora DEBRIX, accessed 25 February 2021,

https://journals.uvic.ca/index.php/ctheory/article/view/14605/5462

BOURDIEU, Pierre, BOLTANSKI, Luc, CASTEL, Robert, CHAMBOREDON, Jean-Claude, SCHNAPPER, Dominique (1998). Photography: A Middle-brow Art. Cambridge: Polity Press, ISBN 0-7456-0523-0.

de CERTEAU, Michel (1988). The Writing of History, translated by Tom Conley. New York: Columbia University Press. ISBN 0-2310-5575-7.

DAMMBECK, Lutz (2008). Konstrukcja i estetyzacja archiwów/The Construction \& Aestheticisation of Archives. In: ZIÓLKOWSKA, Magdalena, LEŚNIAK, Andrzej (eds). Tytuł roboczy: archiwum \# 1. Łódź: ms2 Muzeum Sztuki, pp. 44-54. ISBN 978-83-87937-57-7.

DERRIDA, Jacques (1995). Archive Fever: A Freudian Impression, translated by E. Prenowitz. In: Diacritics, vol. 25, no 2, pp. 9-10, accessed 21 December 2020, http://beforebefore. net/149a/w11/media/Derrida-Archive_Fever_A_Freudian_Impression.pdf

van DIJCK, José (2007). Mediated Memories in the Digital Age. Standford University Press. ISBN 9780804756242.

DROZDOWSKI, Rafał (2009). Zdjęcia w sieci. Kierunkująca ina-znaczająca rama prezentacyjna Internetu. In: FERENC, Tomasz, OLECHNICKI, Krzysztof (eds). Obrazy w sieci. Socjologia $i$ antropologia ikonosfery Internetu. Toruń: Wydawnictwo Naukowe UAM, ISBN 978-83-2312323-1.

ERNST, Wolfgang (2011). Archive, Storage, Entropy: Tempor(e)alities of Photography. In: PIJARSKI, Krzysztof (ed.). Archiwum jako projekt: The Archive as Project. Warszawa: Fundacja Archeologia Fotografii, ISBN 978-83-933045-8-5.

FEATHERSTONE, Mike (2000). Archiving Cultures. In: The British Journal of Sociology, no 51 (1), pp. 161-184.

FRYDRYCZAK, Beata (2002). Świat jako kolek.cja. Próba analizy estetycznej natury nowoczesności. Poznań: Wydawnictwo Fundacji Humaniora, ISBN 83-7112-145-8.

GARLICKA, Aleksandra (1989). Druga wystawa fotografii robotniczej. In: KURASIAK, Małgorzata (ed.). Robotnicy. II wystawa fotografii robotniczej. Zdjecia z lat 1881-1946. Katalog wystawy. Warszawa: Wydawnictwo Centralnego Biura Wystaw Artystycznych.

GILLIAN, Rose (2007). Visual Methodologies: An Introduction to the Interpretation of Visual Materials. London, Thousand Oaks, New Delhi: Sage Publications, ISBN: 978-1-4129-2190- 9.

JENSEN, Ulfe J. (2000). Cultural Heritage, Liberal Education, and Human Flourishing. In:

AVRAMI, Erica, MASON, Randall, de la TORRE, Marta (eds), Values and Heritage

Conservation: Research Report. Los Angeles: The Getty Conservation Institute, pp. 38-43,

accessed 19 March 2021, https://www.getty.edu/conservation/publications_resources/pdf_ publications/pdf/valuesrpt.pdf

KARPIŃSKA, Grażyna Ewa (2014). Stare źródła w nowych mediach. O repozytorium cyfrowym zbioru „Robotnicy w XIX i XX wieku”. In: CHORAŻYCZEWSKI, Waldemar, PIASEK, Wojciech, ROSA, Agnieszka (eds). Toruńskie Konfrontacje Archiwalne. Vol. 4. Nowa archiwistylea - Archiwa $i$ archiwistylea w późnonowoczesnym kontekście kulturowym. Toruń: Wydawnictwo Naukowe UMK, pp. 223-236, ISBN 978-83-231-3332-2.

de KERCKHOVE, Derrick (1998). The Skin of Culture: Investigating the New Electronic Reality. London: Gardens Book, ISBN 978-0749424800. 
KRACAUER, Siegfried (1995). The Mass Ornament: Weimar Essays, translated by Th. Y. Levin. Cambridge-London: Harvard University Press, ISBN 0-674-55162-1.

KURASIAK, Małgorzata (1989). Robotnicy. II wystawa fotografii robotniczej. Zdjecia z lat 1881-1946. Katalog wystawy. Warszawa: Wydawnictwo Centralnego Biura Wystaw Artystycznych.

MANOVICH, Lev (2001). The Language of New Media. Massachusetts: MIT Press, ISBN 0-26213374-1.

MURZYN, Monika A. (2007). Dziedzictwo kulturowe w okresie przemian: szanse i wyzwania. In: MURZYN, Monika A., PURCHLA, Jacek (eds). Driedzictwo kulturowe XXI wieku. Szanse i wyzwania. Kraków: Międzynarodowe Centrum Kultury, ISBN 978-83-89273-47-5.

NORA, Pierre (1989). Between Memory and History: les lieux de mémoire. In: Representations, 1989, no 26 (Spring), pp. 7-24.

STEEDMAN, Carolyn (2001). Dust. The Archive and Cultural History. Manchester: Manchester University Press, ISBN 0719060141.

RICOEUR, Paul (2006). Memory, History, Forgetting, translated by Kathleen Blamey and David Pellauer. Chicago and London: The University of Chicago Press, ISBN 0-226-71341-5.

SEKULA, Allan (2002). Reading an archive: Photography between labour and capital. In: WELLS, Liz (ed.). The Photography Reader. London and New York: Routledge, ISBN $97-$ 80415-2466-13.

SIKORA, Sławomir (2004). Między przezroczystością a nieprzezroczystością: aporia fotografii. In: PELCZYŃSKI, Grzegorz, VORBRICH, Ryszard (eds). Antropologia wobec fotografii i filmu. Poznań: Biblioteka Telgte. ISBN 83-89873-40-0.

SULIMA, Roch (1992). Stowo i etos. Szkice o kulturze. Kraków: Fundacja Artystyczna Związku Młodzieży Wiejskiej „Galicja”.

SZTANDARA, Małgorzata (2001). Fotografia - „opowieść” o skończoności życia. In: GLEŃ, Adrian, KOWALSKI, Piotr (eds). Obecność i przemijanie. Fenomen poczqatku i końca w kulturze $i$ literaturze wspótczesnej. Opole: Wydawnictwo UO, ISBN 83-8887-96-83.

WILKOWSKI, Marcin (2013). Co sie dzieje z archiwum w internecie? Kilka watków teoretycznych. In: ZIECTAL, Katarzyna (ed.), Archiwistyka społeczna. Warszawa: Ośrodek KARTA, pp. 53-58, ISBN 978-83-61283-87-4, https://ksiegarnia.karta.org.pl/wp-content/uploads/2017/11/ Archiwa_spoleczne_podrecznik.pdf (accessed 28 February 2021).

WILKOWSKI, Marcin (2013). Wprowadzenie do bistorii cyfrowej. Gdańsk: Instytut kultury miejskiej, ISBN 978-83-64610-00-4, http://dane.historiaimedia.org/hc/2/wprowadzenie_ do_historii_cyfrowej_wilkowski.pdf, (accessed 2 March 2021).

WRÓBLEWSKI, Filip (2019). Archiwa a etnografia. In: Kultura i Społeczeństwo, (1), pp. 45-67.

ZAWOJSKI, Piotr (2000). Elektronicz̨ne obrazoświaty. Mięży sžtuk.q a technologiq. Kielce: Wydawnictwo Szumacher, ISBN 83-86168-32-3.

\section{Internet sources}

https:// fotografierobotnikow.uni.lodz.pl/ 